\title{
MODEL PEMBELAJARAN BERBASIS NILAI PENDIDIKAN KARAKTER UNTUK GENERASI INDONESIA ABAD 21
}

\author{
Amran' ${ }^{1}$ Ismail Jasin ${ }^{2}$, Magfirah Perkasa ${ }^{3}$, Muhammad Satriawan ${ }^{4}$, Muhammad Irwansyah $^{5}$ \\ 1,2,3,4,5Sekolah Tinggi Keguruan dan Ilmu Pendidikan (STKIP) BIMA \\ 1,2,3,4,5Jalan Piere Tendean, Mpunda, Kota Bima, Indonesia \\ Email: ran_bima@yahoo.com¹, ismail@gmail.com², magfirah@gmail.com³ \\ satriawan@gmail.com ${ }^{4}$, irwansyahmuh44@gmail.com ${ }^{5}$
}

\begin{abstract}
Abstrak:
Penelitian ini bertujuan untuk mengembangkan dan mengetahui kelayakan model pembelajaran karakter berbasis nilai pendidikan karakter dalam membentuk generasi emas Indonesia 2045. Model pengembangan diadaptasi dari model Dick \& Carey dengan subjek uji coba produk adalah siswa kelas XI pada beberapa sekolah di Nusa Tenggara Barat. Model pembelajaran karakter diimplementasikan dalam mata pelajaran biologi, kimia dan fisika melalui perangkat pembelajaran yang telah dikembangkan dengan sintaks model pembelajaran karakter. Indikator penilaian karakter diadaptasi dari indikator pendidikan karakter yang dikombinasikan dengan keterampilan abad 21 . Instrumen pengumpulan data meliputi penilaian diri dan lembar observasi. Hasil penelitian menunjukkan bahwa model pembelajaran karakter yang dikembangkan memiliki sintaks: kumpulkan, rembukkan, analisis, komunikasikan dan terapkan. Adapun model pembelajaran karakter berbasis nilai pendidikan karakter yang dikembangkan layak digunakan dengan kategori sangat baik.
\end{abstract}

\begin{abstract}
:
The study aimed to develop and to reveal the appropriate character learning model based on character education values to prepare Indonesian golden generation in 2045. The developing model adapted from Dick \& Carey and the product was tested in the 11th grade students of senior high school that located in West Nusa Tenggara. The character learning model was implemented into biology, chemistry and physics subjects by using character learning model syntax in learning tools. The indicators of measuring the characters were adapted from Indonesian golden generation character indicators and 21st century skill indicators. The instrument for data collection included character self-assessment and observation sheets. The result showed that (1) the character learning model which was developed has five syntax namely collecting, discussing, analyzing, communicating and applying; the problem and its solution were focussed on environment, society and economic issue; (2) character learning model based on character education values was valid to use with very good category.
\end{abstract}

Kata kunci:

Model Pembelajaran Karakter, Pendidikan Karakter, Generasi Emas Indonesia

How to Cite: Amran, Jasin, I., Perkasa, M., \& Satriawan, M. (2019). Model Pembelajaran Berbasis Nilai Pendidikan Karakter untuk Generasi Indonesia Abad 21. Lentera Pendidikan: Jurnal Ilmu Tarbiyah dan Keguruan, 22(2), 233-242. 


\section{PENDAHULUAN}

Indonesia pada tahun 2045 akan mendapatkan bonus demografi (demographic dividend) berupa jumlah usia produktif (15-64 tahun) masyarakatnya yang paling besar sepanjang sejarah. Jika kesempatan ini dapat dikelola dan diberdayakan dengan baik, maka jumlah usia produktif Indonesia ini akan menjadi bonus demografi yang sangat berharga. Sebaliknya, jika tidak dikelola dengan baik, maka jumlah usia produktif yang dimiliki oleh Indonesia justru akan menjadi bencana demografi (demographic disaster) yang berdampak pada stabilitas negara (Dongoran, 2014). Oleh karena itu, peran pendidikan, baik melalui inovasi maupun revolusi pendidikan sangat diharapkan untuk mempersiapkan terciptanya generasi emas yang dapat bersaing pada kehidupan abad 21.

Pendidikan karakter merupakan suatu keniscayaan dalam upaya menghadapi berbagai tantangan pergeseran karakter yang dihadapi saat ini (Komara, 2018: 18). Generasi yang berkarakter generasi emas harus memiliki kompetensi, karakter, nilai religius, sikap, pola pikir, konsep, dan berperadaban unggul dengan wawasan yang cerdas serta berpikiran berkelanjutan sehingga menumbuhkan tanggung jawab dan kontribusi nyata dalam mewujudkan lingkungan dan kehidupan yang sehat, damai, bermartabat, dan berkelanjutan seutuhnya (Irwansyah \& Ariyansyah, 2019; Agus, 2016). Karakter generasi emas juga harus memliki keterampilan abad 21. Kereluik, Mishra, Fahnoe, \& Laura (2013) menyatakan bahwa terdapat tiga kompetensi abad 21 yang harus dimiliki oleh para profesional yaitu foundational knowledge (to know), meta knowledge (to act) dan humanistic knowledge (to value). Tiga kompetensi dasar tersebut dijabarkan, diantaranya pengetahuan dasar utama, literasi digital dan informasi, pengetahuan tentang multidisiplin, keterampilan berpikir kritis dan pemecahan masalah, keterampilan berkomunikasi dan berkolaborasi, kreativitas dan inovasi, kecakapan hidup, keterampilan kerja, kepemimpinan, kompetensi budaya dan kesadaran beretika dan penguasaan emosi.

Nilai-nilai yang diharapkan dapat membentuk karakter generasi emas, yaitu religius, jujur, toleransi terhadap keberagaman, disiplin, kerja keras, kreatif, mandiri, demokratis, rasa ingin tahu, semangat nasionalisme, cinta tanah air, berprestasi, komunikatif, cinta damai, gemar membaca, peduli lingkungan, peduli sosial dan bertanggung jawab (Fahmy, Bahtiar, Rahim, \& Malik, 2015; Manullang, 2013). Sejalan dengan hal tersebut, Triadis dalam Hussein (2017) mendefinisikan bahwa sikap sebagai karakteristik seseorang yang mengacu pada perilaku positif maupun negatif dan cerminan dari perasaan serta pengetahuan terhadap konsep atau subjek tertentu. Karakter berhubungan dengan segala hal yang berkaitan dengan penampilan maupun hubungan seseorang dengan lingkungannya.

Cronbach dalam Rokhman, Syaifudin, \& Yulianti (2014) menguraikan bahwa karakter merupakan salah satu aspek kepribadian. Pendidikan karakter mengacu pada pedoman kurikulum yang dapat mengedukasi siswa tentang kepedulian, kewarganegaraan, rasa hormat, tanggung jawab, dan kepercayaan. Permalasahan tentang bergesernya nilai-nilai karakter generasi muda semakin marak akhir-akhir 
ini. Beberapa kasus tentang kurangnya kepedulian sosial dan profesionalisme muncul karena dangkalnya penanaman karakter serta tidak tersisipnya nilai-nilai karakter mulia dalam proses pembelajaran sejak dini. Media massa saat ini dihiasi oleh pemberitaan tentang karakter dan sikap generasi muda yang mengarah pada hal-hal negatif. Jika dibiarkan tanpa pengendalian, penanaman, pengembangan, dan penguatan karakter sejak dini, maka permasalahan seperti ini akan menjadi ciri khas negatif dari generasi yang akan datang.

Salah satu penyebab hal tersebut terjadi karena tidak tersisipnya nilai-nilai karakter dalam proses pembelajaran. Berdasarkan hasil wawancara singkat dengan perwakilan guru dan akademisi LPTK di beberapa kabupaten di Provinsi Nusa Tenggara Barat, pembelajaran berbasis penguatan pendidikan karakter serta pendidikan untuk pengembangan berkelanjutan yang memuat nilai-nilai dan wawasan berkelanjutan juga belum diimplementasikan secara luas dalam pendidikan. Kompetensi tersebut masih dianggap asing dan hampir tidak pernah dinilai dengan baik serta minim disisipkan dalam proses pembelajaran oleh guru maupun dosen sehingga masih banyak generasi muda yang belum memiliki kesadaran beretika dan penguasaan emosi, menguasai literasi digital dan informasi serta keterampilan berkomunikasi dan berkolaborasi dalam proses pembelajaran maupun kesehariannya.

Permasalahan lain yang juga dihadapi oleh pendidik pada masa sekarang adalah tidak tersedianya inovasi pembelajaran berupa model pembelajaran berkarakter yang dapat dijadikan landasan penerapan dalam proses pembelajaran untuk menumbuhkembangkan sikap dan karakter mulia, bahkan pada jenjang pendidikan dasar. Model pembelajaran karakter berbasis nilai pendidikan karakter untuk membentuk generasi emas yang berkarakter yang tertuang dalam bentuk RPP, LKS, instrumen penilaian untuk mengukur karakter. Momen 100 tahun kemerdekaan akan menjadi tolak ukur ketercapaian dan keberhasilan pembangunan Indonesia dalam berbagai bidang, salah satunya bidang pendidikan dan pemberdayaan SDM. Pendidikan sebagai salah satu pilar pembangunan SDM perlu melakukan inovasi agar bonus demografi ini dapat diarahkan ke arah yang positif dan menguntungkan pembangunan Indonesia.

Pengembangan model pembelajaran berkarakter ini akan menjadi salah satu solusi permasalahan kemerosotan moral dan akhlak generasi muda serta dapat menjadi ujung tombak perbaikan karakter generasi muda Indonesia melalui implementasi dalam bidang pendidikan, sehingga Indonesia dapat membentuk generasi emas. Melalui pengembangan ini, model pembelajaran berkarakter yang dikembangkan termasuk dalam prioritas riset nasional dan menjadi salah satu bagian dari solusi peningkatan kualitas SDM Indonesia mengingat pentingnya penerapan pembelajaran berorientasi pendidikan karakter untuk membentuk SDM yang berkualitas, berkarakter, dan berakhlak mulia sedini mungkin, serta untuk menyongsong cita-cita pembentukan generasi emas Indonesia tahun 2045.

Hasil penelitian ini akan menjadi dasar penelitian pengembangan selanjutnya 
dalam bidang pendidikan karakter dan pendidikan untuk pengembangan berkelanjutan. Oleh karena itu, untuk menyelesaikan beberapa masalah tersebut, perlu dikembangkan model pembelajaran karakter yang berbasis nilai pendidikan karakter yang bertujuan untuk membentuk generasi emas yang berkarakter dan berakhlak mulia guna menyongsong cita-cita pembentukan karakter generasi emas Indonesia tahun 2045 serta menjawab tantangan abad 21.

\section{METODE PENELITIAN}

Penelitian ini merupakan penelitian dan pengembangan dengan model pengembangan yang diadaptasi dari model Dick \& Carey (2001) dengan tahapan, yaitu pendahuluan, analisis, perancangan, pengembangan, dan penyebaran. Pada tahap pendahuluan dilakukan analisis kebutuhan pengguna dan studi literatur. Hasil yang dilakukan pada tahap ini selanjutnya dijadikan dasar pada tahap analisis. Tahap analisis dilakukan untuk menganalisis komponen-komponen utama pengembangan model pembelajaran, yaitu dengan menganalisis siswa, menganalisis silabus, menganalisis struktur isi dan konsep, dan menganalisis tujuan pembelajaran. Tahap perancangan meliputi perumusan tujuan khusus dan perumusan sintaks model pembelajaran berkarakter yang ingin dikembangkan berdasarkan tahap pendahuluan dan analisis. Selanjutnya, tahap pengembangan dilakukan dengan mengembangkan produk berupa model pembelajaran karakter berbasis nilai pendidikan karakter yang tertuang dalam RPP, LKS dan instrumen penelitian. Terdapat dua hal utama yang dilakukan dalam tahap pengembangan yaitu: (1) perumusan dan penyusunan RPP, LKS dan instrumen penelitian; dan (2) penyusunan lembar validasi model pembelajaran berkarakter. Draf produk yang telah dikembangkan selanjutnya divalidasi oleh ahli. Hasil validasi oleh ahli yang memenuhi validitas, layak untuk diujicobakan. Tahap berikutnya adalah tahap penyebaran, dilakukan untuk mengetahui ketercapaian tujuan pengembangan dan tingkat kelayakan produk model pembelajaran karakter. Tahap penyebaran dilakukan dengan menguji produk model pembelajaran karakter pada siswa perwakilan SMA tiap kabupaten/kota se-provinsi NTB.

Subjek uji coba sebanyak enam sekolah di Provinsi Nusa Tenggara Barat (NTB). Data pada penelitian ini dikumpulkan dengan teknik non-tes yang meliputi observasi, wawancara, validasi, angket, dan dokumentasi gambar. Observasi dilakukan untuk mengamati proses pelaksanaan dan keterlaksanaan pembelajaran dengan menggunakan model pembelajaran berkarakter yang dikembangkan pada tahap pengujian. Wawancara dilakukan untuk mengetahui lebih lanjut tentang kebutuhan pengguna terhadap produk yang dikembangkan. Wawancara dilakukan kepada perwakilan guru, dosen dan akademisi di Provinsi NTB. Validasi dilakukan pada tahap pengembangan dengan melakukan validasi kepada ahli terhadap produk yang telah dikembangkan. Dokumentasi gambar merupakan data pendukung untuk memperkuat data lain yang memuat gambaran proses pelaksanaan pembelajaran menggunakan produk model pembelajaran berkarakter yang dikembangkan. 


\section{HASIL PENELITIAN DAN PEMBAHASAN}

Pada tahap pendahuluan dilakukan need assesment. Beberapa sekolah yang dijadikan lokasi dalam melakukan wawancara singkat dengan guru mata pelajaran kimia, biologi dan fisika, yaitu SMAN 2 Kota Bima, SMAN 1 Bolo (Kabupaten Bima), SMAN 1 Dompu (Kabupaten Dompu), SMAN 2 Dompu (Kabupaten Dompu), SMAN 1 Kota Mataram, SMAN 3 Kota Mataram, SMAN 1 Gunungsari (Kabupaten Lombok Barat), dan SMAN 1 Narmada (Kabupaten Lombok Barat). Namun, need assesment hanya dilakukan pada enam sekolah diantara delapan sekolah tersebut, yaitu SMAN 2 Kota Bima, SMAN 1 Bolo (Kabupaten Bima), SMAN 1 Dompu (Kabupaten Dompu), SMAN 2 Dompu (Kabupaten Dompu), SMAN 3 Kota Mataram dan SMAN 1 Narmada (Kabupaten Lombok Barat). Need assesment juga hanya sebatas sikap yang dituntut pada kehidupan abad 21 yang berkaitan dengan 4Cs (communication, critical thinking, collaboration $\mathcal{E}$ creativity). Indikator sikap 4Cs diadaptasi dari Assessment and Teaching of 21st Century Skills (ATC21S) (Griffin, McGaw, \& Care, 2012; P21, 2011).

Berdasarkan hasil wawancara, observasi dan need assesment yang dilakukan pada enam sekolah tersebut, diperoleh informasi bahwa model pembelajaran untuk mengimplementasikan konsep pendidikan karakter belum diajarkan oleh guru, sebagian guru masih menitikberatkan evaluasi pembelajaran pada penilaian aspek pengetahuan, penilaian aspek sikap dan keterampilan khususnya yang berkaitan dengan pendidikan karakter masih minim dilakukan pada proses pembelajaran.

Tahap analisis dilakukan analisis hasil need assesment, berkaitan dengan sikap yang dituntut pada kehidupan abad 21 disebut dengan 4Cs (communication, critical thinking, collaboration $\mathcal{E}$ creativity). Berdasarkan hasil angket siswa tentang kebiasaan mereka shari-hari yang berkaitan dengan nilai pendidikan karakter menggambarkan bahwa siswa memiliki pengetahuan yang cukup baik. Di samping itu, berdasarkan hasil assesmen sikap diperoleh informasi bahwa sebagian besar siswa belum mampu mencapai kategori tinggi. Sebaran data siswa masih terbilang banyak pada kategori rendah. Hal ini menunjukkan bahwa sikap pembelajaran abad 21 memang penting dan urgen untuk disisipkan dalam pembelajaran.

Model pembelajaran yang dikembangkan diterapkan pada tiga mata pelajaran yaitu biologi, kimia, dan fisika. Pada mata pelajaran biologi dipilih materi yang sesuai dengan karakteristik model pembelajaran yaitu materi sistem reproduksi. Pada mata pelajaran kimia dipilih materi yang sesuai dengan karakteristik model pembelajaran yaitu materi koloid. Pada mata pelajaran fisika dipilih materi yang sesuai dengan karakteristik model pembelajaran, yaitu materi dampak pemanasan global.

Kemendikbud (2013: 6) menyatakan sistematika RPP yang dikembangkan dengan kurikulum 2013 memiliki muatan yang dijabarkan sebagai berikut: identitas sekolah, identitas mata pelajaran, kelas/semester, materi pokok, alokasi waktu, tujuan pembelajaran yang dirumuskan berdasarkan KD, kompetensi dasar dan indikator pencapaian kompetensi, materi pembelajaran, metode pembelajaran, media pembelajaran, sumber belajar, langkah pembelajaran, dan penilaian hasil pembelajaran. 
Pada tahap perancangan, model pembelajaran yang dikembangkan dirancang sintaks dan tujuan dengan lengkap. Model pembelajaran harus memenuhi lima unsur karakteristik model, yaitu: (1) sintaks (syntax), (2) sistem sosial (social system), (3) prinsip reaksi (principles of reaction), (4) sistem pendukung (support system), dan (5) dampak instruksional dan pengiring (instructional $\mathcal{E}$ nurturant effects) (B. Weil \& Calhoun, 2000).

Adapun uraian sintaks model pembelajaran karakter dijabarkan berikut.

\section{Kumpulkan}

Siswa diarahkan untuk mengumpulkan informasi yang berkaitan dengan materi pembelajaran berdasarkan pengalamannya sehari-hari. Informasi tersebut dapat berupa masalah yang sedang dihadapi masyarakat sekitar maupun yang menjadi gejala masalah yang belum meresahkan masyarakat. Pada tahap ini, diharapkan sikap yang muncul yaitu toleransi, kreatif, rasa ingin tahu, komunikatif, peduli sosial, peduli lingkungan dan tanggung jawab.

\section{Rembukkan}

Informasi tentang materi pembelajaran dalam bentuk masalah yang telah dikumpulkan selanjutnya dirembukkan bersama rekan sekelompok. Pada tahap ini juga, siswa dapat merembukkan tentang alternatif solusi terhadap isu permasalahan yang telah dikumpulkan. Sikap yang diharapkan muncul pada tahap ini, yaitu toleransi, disiplin, kerja keras, kreatif, mandiri, demokratis, rasa ingin tahu, dan cinta damai.

\section{Analisis}

Tahap analisis merupakan tahap untuk menganalisis lebih lanjut dan lebih rasional serta untuk mengolah informasi tentang kemungkinan alternatif solusi. Pada tahap ini, alternatif solusi yang disediakan dianalisis lebih lanjut hingga siswa dapat memilih solusi yang paling sesuai untuk dapat diterapkan sebagai penyelesaian masalah. Sikap yang diharapkan dapat disisipkan melalui tahapan ini, yaitu jujur, toleransi terhadap keberagaman, disiplin, kerja keras, kreatif, mandiri, rasa ingin tahu, semangat nasionalisme, cinta tanah air, berprestasi, cinta damai, peduli lingkungan, peduli sosial, dan bertanggung jawab.

\section{Komunikasikan}

Solusi yang paling sesuai dengan isu permasalahan selanjutnya adalah mengkomunikasikan kepada guru maupun perwakilan masyarakat yang menjadi target masalah. Komunikasi yang baik antara guru, rekan sekelompok maupun masyarakat dapat merangsang siswa untuk dapat mengembangkan dan menumbuhkan sikap religius, hormat pada yang lebih tua, jujur, toleransi terhadap keberagaman, disiplin, kerja keras, kreatif, mandiri, demokratis, semangat nasionalisme, cinta tanah air, berprestasi, komunikatif, cinta damai, peduli lingkungan, peduli sosial, dan bertanggung jawab. 


\section{Terapkan}

Pada tahapan ini, alternatif solusi yang telah dipilih tidak hanya dikomunikasikan kepada guru maupun perwakilan masyarakat, tetapi juga langsung diterapkan agar fungsi alternatif solusi tersebut dapat dioptimalkan dengan baik. Sikap yang diharapkan muncul, yaitu religius, jujur, toleransi terhadap keberagaman, disiplin, kerja keras, kreatif, mandiri, demokratis, rasa ingin tahu, semangat nasionalisme, cinta tanah air, berprestasi, komunikatif, cinta damai, gemar membaca, peduli lingkungan, peduli sosial, dan bertanggung jawab.

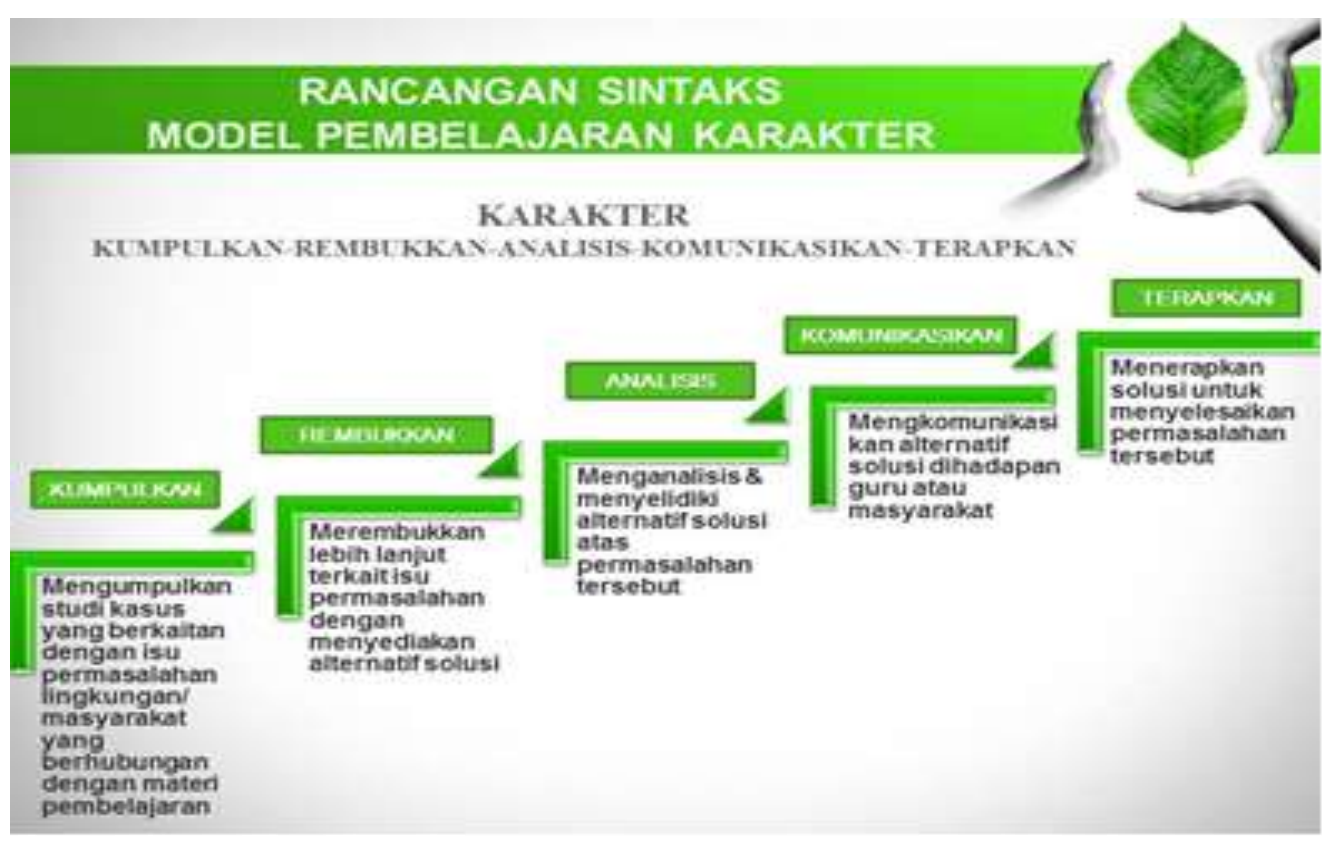

Gambar 1. Sintaks Model Pembelajaran Karakter

Pada tahap pengembangan, dilakukan penyusunan perangkat pembelajaran menggunakan sintaks model pembelajaran karakter dan validasi produk. Sintaks model pembelajaran karakter diwujudkan dalam draft produk yang dikembangkan berupa RPP, LKS dan instrumen penilaian karakter. RPP merupakan seluruh rangkaian kegiatan pembelajaran untuk mencapai tujuan pembelajaran yang ditentukan tiap satu kali pertemuan atau lebih. RPP dikembangkan berdasarkan kurikulum 2013 dengan model pembelajaran karakter yang disesuaikan dengan pendekatan saintifik. Sistematika RPP yang dikembangkan dengan kurikulum 2013 memiliki muatan, antara lain: identitas sekolah, identitas mata pelajaran, kelas/semester, materi pokok, alokasi waktu, tujuan pembelajaran yang dirumuskan berdasarkan KD, kompetensi dasar, indikator pencapaian kompetensi, materi pembelajaran, metode pembelajaran, media pembelajaran, sumber belajar, langkah pembelajaran, dan penilaian hasil pembelajaran.

LKS dikembangkan dengan menggunakan sintaks model pembelajaran karakter, yaitu kumpulkan, rembukkan, analisis, komunikasikan dan terapkan. Pada 
mata pelajaran biologi terdapat dua kegiatan siswa yang dikembangkan. Pada mata pelajaran kimia terdapat tiga kegiatan siswa yang dikembangkan. Selanjutnya, pada mata pelajaran fisika satu kegiatan siswa yang dikembangkan. Instrumen penilaian karakter dikembangkan dalam bentuk lembar penilaian diri dengan butir pernyataan sebanyak 34 butir yang mewakili indikator setiap sikap/karakter yang ingin diukur. Indikator sikap/karakter tersebut merupakan adaptasi dari indikator karakter pada konsep pendidikan karakter yang dimodifikasi dengan sikap abad 21. Terdapat beberapa sikap (karakter) yang menjadi objek penilaian dalam penerapan model pembelajaran karakter, yaitu jujur, toleransi terhadap keberagaman, disiplin, kerja keras, kreatif, mandiri, demokratis, rasa ingin tahu, semangat nasionalisme, cinta tanah air, berprestasi, komunikatif, cinta damai, gemar membaca, peduli lingkungan, peduli sosial dan bertanggung jawab.

Pada tahap pengembangan juga dilakukan validasi. Validasi yang dilakukan bertujuan untuk mengetahui kelayakan produk yang dikembangkan untuk mencapai tujuan pengembangan berdasarkan penilaian secara kualitatif dari segi konstruk dan isi oleh para ahli. Hasil validasi oleh ahli disajikan pada tabel 1.

Tabel 1. Hasil Validasi Ahli

\begin{tabular}{ccccc}
\hline \multirow{2}{*}{ No. } & \multirow{2}{*}{ Validator } & \multicolumn{3}{c}{ Aspek Penilaian } \\
\cline { 3 - 5 } & & RPP & LKS & Instrumen Penilaian \\
\hline 1. & A & 84 & 42 & 16 \\
2. & B & 80 & 38 & 14 \\
3. & C & 82 & 40 & 15 \\
Rata-rata & 82 & 40 & 15 \\
Kategori & Sangat Baik & Sangat Baik & Sangat Baik \\
Kelayakan & & & &
\end{tabular}

Berdasarkan kategori kelayakan produk yang disajikan, data skor validasi produk oleh dosen ahli menunjukkan produk bahan ajar yang terdiri dari RPS, diklat kuliah dan instrumen penilaian semuanya memiliki kelayakan "sangat baik". Adapun yang menjadi validator adalah dosen yang memiliki kapasitas dan kepakaran dalam aspek pengembangan perangkat pembelajaran, bahan ajar dan menguasai konten materi. Gambaran data hasil uji terbatas ditunjukkan pada gambar 2 berikut.

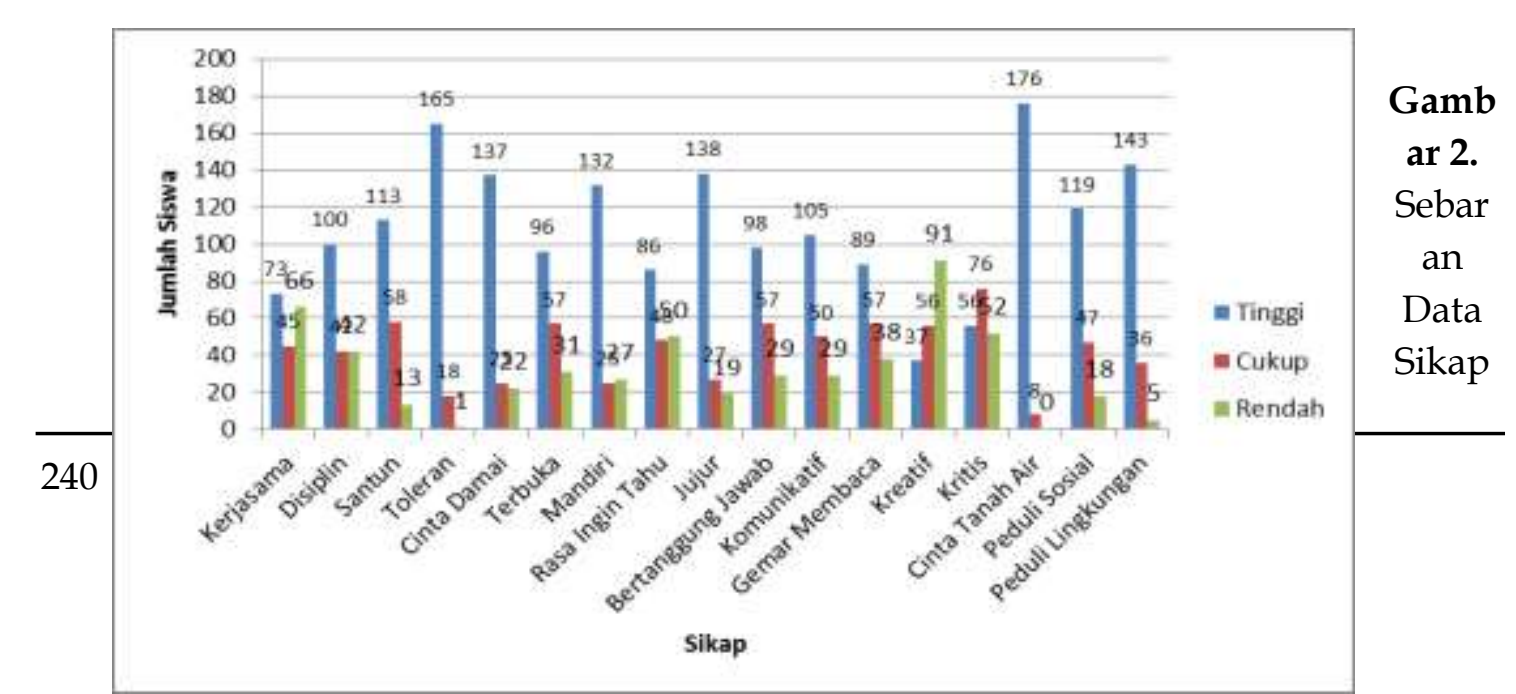


Siswa

Pada pengujian, jumlah siswa sebagai subjek pada uji terbatas sebanyak 184 orang yang terbagi dalam enam sekolah. Hasil uji terbatas digunakan sebagai bahan revisi II. Produk yang digunakan direvisi dari segi keterbacaan produk, ketercapaian tujuan pembelajaran dan pengembangan serta alokasi waktu yang berhubungan dengan pelaksanaan secara teknis dari produk pengembangan. Jika produk telah memenuhi kedua aspek bahan revisi, baik dari kelayakan maupun ketercapaian tujuan pengembangan maka produk tidak perlu direvisi. Berdasarkan gambaran data yang ditunjukkan pada gambar 2, diperoleh informasi bahwa penerapan model pembelajaran karakter dinilai dapat meningkatkan sikap/karakter siswa sesuai dengan tujuan pengembangan.

\section{SIMPULAN}

Model pembelajaran yang dikembangkan bernama "model pembelajaran karakter" dengan urutan sintaks, yakni kumpulkan, rembukkan, analisis, komunikasikan dan terapkan. Model pembelajaran karakter berbasis nilai pendidikan karakter layak untuk digunakan dengan tujuan untuk membentuk generasi emas Indonesia abad 21 yang berkarakter dengan kategori kelayakan "sangat baik" dan efektif untuk digunakan sebagai salah satu model pembelajaran untuk menerapkan konsep pendidikan karakter.

\section{DAFTAR PUSTAKA}

Agus, C. (2016). Pendidikan untuk Generasi Emas. Harian Bernas, p. 4.

B. Weil, J., \& Calhoun. (2000). Models of Teaching. New York: Person Education Company.

Dick, W., \& Carey, L. (2001). The Systematic Design of Instruction (5th ed.). Florida: Addison-Wesley Educational Publishers Inc.

Dongoran, F. R. (2014). Paradigma Membangun Generasi Emas 2045 dalam Perspektif Filsafat Pendidikan. Jurnal Tabularasa PPs UNIMED, 11(1), 61-76.

Fahmy, R., Bahtiar, N., Rahim, R., \& Malik, M. (2015). Measuring Student Perceptions to Personal Characters Building in Education: An Indonesian Case in Impleme nting A New Curriculum in High School. Procedia - Procedia Computer Science, 211, 851-858. https:// doi.org/10.1016/j.sbspro.2015.11.112

Griffin, P., McGaw, B., \& Care, E. (2012). Assessment and Teaching of 21st Century Skills. Dordrecht, NL: Springer.

Hussein, Z. (2017). Leading to Intention: The Role of Attitude in Relation to Technology Acceptance Model in E-Learning. Procedia - Procedia Computer Science, 105 (December 2016), 159-164. https://doi.org/10.1016 /j.procs.2017. 01.196

Irwansyah, M., \& Ariyansyah. (2019). Perangkat Pembelajaran Biologi Berorientasi Pendidikan Karakter untuk Meningkatkan Sikap dan Pengetahuan Siswa. 
Lentera Pendidikan : Jurnal Ilmu Tarbiyah dan Keguruan, 22(1), 94-102.

Kemendikbud. (2013). Permedikbud Nomor 65 Tahun 2013 Tentang Standar Proses. Jakarta: Kemendikbud.

Kereluik, K., Mishra, P., Fahnoe, C., \& Laura, T. (2013). What Knowledge Is of Most Worth: Teacher Knowledge for 21st Century Learning. Journal of Digital Learning in Teacher Education, 29(4), 127-140.

Komara, E. (2018). Penguatan Pendidikan Karakter dan Pembelajaran Abad 21. SIPATAHOENAN: South-East Asian Journal for Youth, Sports \& Health Education, 4(April), 17-26. Retrieved from https://www.google.com/url?sa=t\&rct=j\&q $=\&$ esrc $=$ s\&source $=$ web\&cd $=1 \&$ cad $=$ rja\&uact $=8 \& v e d=2$ ahUKEwi7x7jLpqfmAh UhheYKHYyeCkIQFjAAegQIBRAC\&url=http\%3A\%2F\%2Fwww.journals.mind amas.com $\% 2$ Findex.php $\% 2$ Fsipatahoenan $\% 2$ Farticle $\% 2$ Fdownload $\% 2 F 99 \%$

2F889\&usg=AOvVaw13Qf8OAqxIic5bcFxTmgC4

Manullang, B. (2013). Grand Desain Pendidikan Karakter Generasi Emas 2045. Jurnal Pendidikan Karakter, 3(1), 1-14.

P21. (2011). Framework for 21st Century Learning. Washington DC: Artnership for 21st Century.

Rokhman, F., Syaifudin, A., \& Yulianti. (2014). Character Education for Golden Generation 2045 (National Character Building for Indonesian Golden Years). Procedia - Social and Behavioral Sciences, 141, 1161-1165. https://doi.org/10.1016 /j.sbspro.2014.05.197 